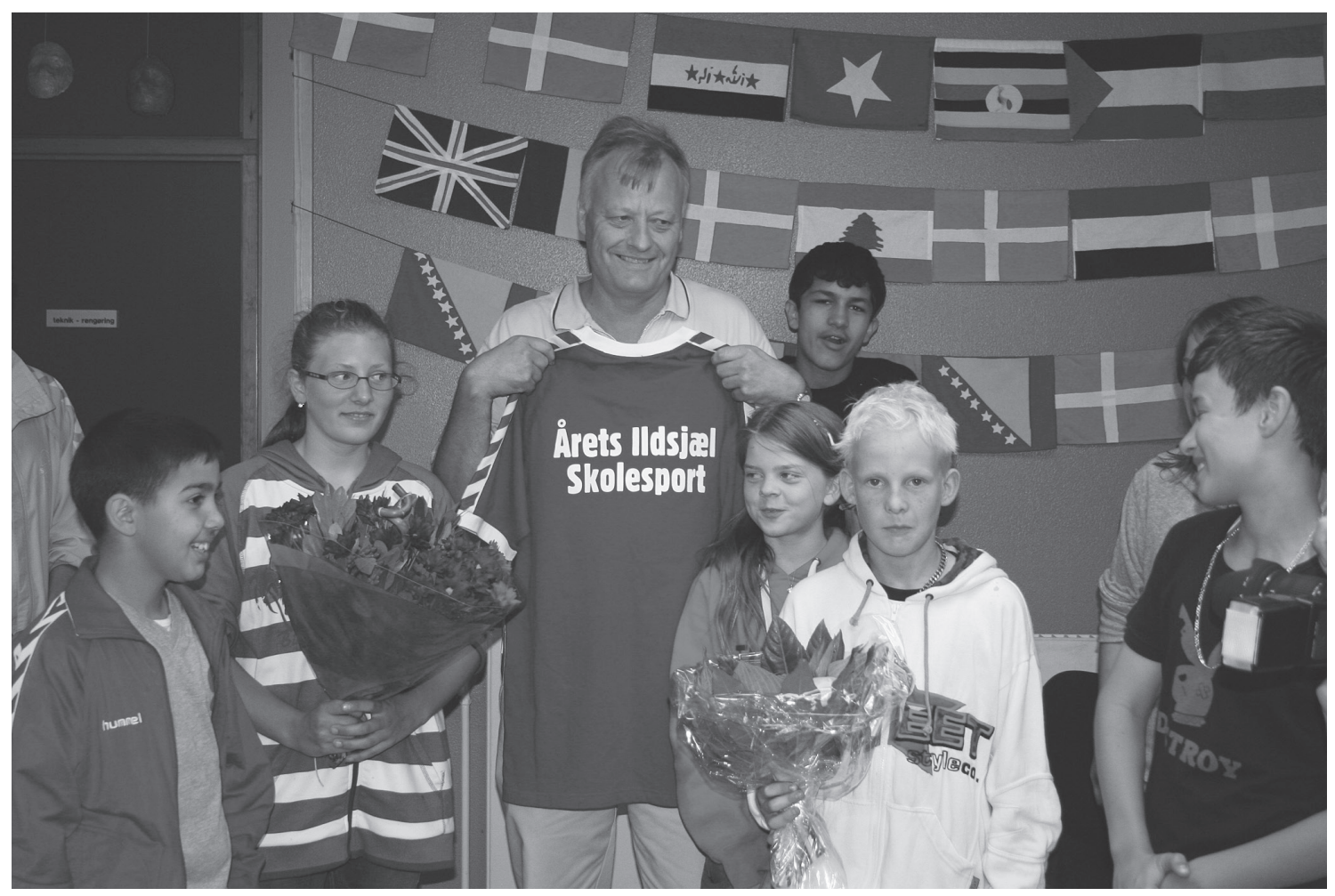

Jesper Hansen fra Munkevængets Skole i Kolding blev som den første udnævnt til Årets Ildsjæl af Dansk Skolesport i 2006. Med stort engagement og lidenskab havde han kæmpet for, at skolens børn skal dyrke mere idræt. I Skolesport udnyttede han sit store netværk i Koldings foreningsliv, så de idrætsusikre børn ikke kun dyrker idræt til skolesport, men også får kendskab til foreningslivet. (Foto udlånt af Dansk Skolesport)

\title{
Hvor skal de foreningsløse børn gå hen og dyrke idræet efter skoletid?
}


"Hvis du i forvejen dagligt ryger ind i nederlag $\mathrm{i}$ skolen, så har du ikke overskud, når du kommer hjem til også at gå et andet sted hen, hvor man måske risikerer at blive ydmyget « (Interview med idrætslærer).

Ovenstående citat stammer fra et interview med en idrætslærer, der er ansat på en folkeskole i Næstved. Interviewet er foretaget i forbindelse med min ph.d.-afhandling (Østergaard, 2011b). Citatet er et eksempel på en af de fortællinger, jeg har mødt hos idrætslærere i forbindelse med afhandlingen og i forbindelse med en evaluering af Projekt Skolesport (Østergaard, 2008). Fortællingen handler om, at der findes en gruppe børn, som af varierende årsager ikke har noget sted at gå hen og dyrke idræt efter skoletid. Det er børn, der typisk ikke er tiltalt af eller fungerer i foreningsidrætten, eller børn, som har forældre, der ikke har tillid til den danske foreningsmodel. Ifølge idrætslærernes udsagn er det børn, som har behov for et alternativt idrætstilbud. Et tilbud, der fungerer efter nogle andre regler og logikker end dem, foreningsidrætten kan tilbyde. De børn, der her er tale om, er børn, der både i politiske og forskningsmæssige sammenhænge igennem de seneste år er blevet sat i kategorier som idratssvage, idratsuvante og idrcetsinaktive.

I det følgende vil jeg ud fra to perspektiver, et politisk og et praksisnært, se på de fortællinger, der er skabt om denne børnegruppe. Med udgangspunkt $\mathrm{i}$ de to perspektiver stiller jeg spørgsmål til måden, gruppen italesættes, samt til måden tiltag målrettet gruppen er udformet på.

Mine analyser og overvejelser bygger på dataindsamling foretaget $i$ forbindelse med evaluering og afhandling. Min metodiske tilgang til indsamling af data har primært været kvalitativ.
Jeg har foretaget observationer af idrætsaktiviteter for børn på skoler og i idrætsforeninger samt foretaget interviews med skolelærere, kommunalt ansatte og frivillige foreningsledere. I forbindelse med evalueringen af skolesport er der også anvendt spørgeskema samt fokusgruppeinterview med børn.

De idrætslærere, jeg har interviewet, er ildsjæle og koordinatorer i to projekter. I afhandlingen indgår ud over Projekt Skolesport også ISA (Idræt og Samvær). ISA er et tiltag under Københavns Kommune, som er oprettet på skoler med mange tosprogede elever, hvor foreningsdeltagelsen er lav. Skolesport og ISA har mange ligheder. Formålet med begge tiltag er at etablere idrætsaktiviteter på skolen efter skoletid, målrettet den målgruppe, jeg i mangel af et bedre begreb i det følgende vælger at kalde de foreningsløse børn. Desuden er hensigten med begge tiltag, at de er brobyggende og pædagogisk dannende, så der opnås kompetencer med henblik på deltagelse $\mathrm{i}$ foreningsidrætten. I begge tiltag er det en idrætslærer, der i forvejen arbejder på skolen, som fungerer som ildsjæl og koordinator. Idrætslæreren står for rekruttering og fastholdelse af elever og for den overordnede planlægning af aktiviteterne. Også udadtil er det idrætslæreren, der danner projektets ansigt. Det er idrætslæreren, der står for kontakt til forældre, kontakt til eventuelle lokale idrætsforeninger om samarbejde og kontakt til kommunen.

Af de interviews og observationer, jeg har foretaget, viser det sig, at idrætslærernes interesse og engagementet i projekterne er drevet af glæden ved idræt og fysisk udfoldelse, men også af et stort socialt engagement. Deres engagement er rodfæstet $\mathrm{i}$ en interesse for at give de foreningsløse børn nogle rammer at udfolde deres fritid i. Idrætslærernes fokus ligger på bør- 
nenes udsathed. De børn, som idrætslærerne har et ønske om at rekruttere og fastholde, er socialt udsatte børn, som ud over en social udsathed også kan have andre problemer at kæmpe med, eksempelvis overvægt eller motoriske vanskeligheder. Set fra idrætslærernes praksisnære perspektiv bliver den væsentligste målsætning med idrætsaktiviteterne i ISA og Skolesport derfor, at de tilrettelægges med udgangspunkt i børnene og deres særlige behov.

I et velfærdsperspektiv vil man politisk set mange ting med idrætten. Man vil skabe mere sundhed, mere integration, forebygge kriminalitet og arbejdsløshed og opbygge social kapital. Medlemskab af foreningsidrætten bliver desuden opfattet som styrkende for demokrati og medborgerskab. I det politiske perspektiv ligger der derfor en anden og langt bredere målsætning bag tiltagene. Det politiske mål med Skolesport og ISA er, at børnene gennem deltagelse i det skoleorganiserede tilbud skal udvikle fysiske og sociale kompetencer, så de kan deltage i foreningslivet. ISA og Skolesport er derfor i lighed med lignende projekter udformet med det mål at gøre børnene til foreningsmedlemmer. Deltagelse i aktiviteterne under Skolesport og ISA er et stadie eller en sluse på vejen mod foreningernes organiserede tilbud (Dansk Skoleidræt og Dansk Idræts-Forbund, 2003, Theilgaard, 2008). Ved at udforske tiltagene fra henholdsvis et praksisnært og et politisk perspektiv, ses en uoverensstemmelse mellem det overordnede projektmål og det praksisnære arbejde.

Anskuer man de to projekters succes ud fra et fysiologisk og sundhedsfremmende perspektiv, er både Skolesport og ISA en succes. Begge projekter formår at tilrettelægge idrætsaktiviteter, der virker tiltrækkende og fastholdende på målgruppen. Ligeledes må projekter, der formår at involvere de foreningsløse børn i idrætsaktivite-

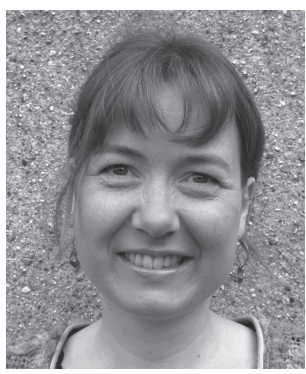

ter efter skoletid, også i et socialpolitisk perspektiv betragtes som en succes. De erfaringer og den viden, som idrætslærerne besidder, gør det muligt at tilrettelægge aktiviteterne, så de matcher målgruppen. Fra et praksisnært perspektiv er tiltagene ikke kun en succes - de er en praktisk nødvendighed, hvis de foreningsløse børn skal have et sted at gå hen og dyrke idræt i fritiden. Det er de, fordi der ifølge idrætslærerne eksisterer forskellige former for barrierer for disse børns foreningsdeltagelse; barrierer, som ikke nødvendigvis nedbrydes gennem deltagelse i projekter som ISA og Skolesport.

Jeg vil i det følgende se på, hvorfor der fra et politisk perspektiv er så stort fokus på, at de foreningsløse børn skal opnå foreningsmedlemskab. For at få svar på det vil jeg spørge til, hvad det er for nogle egenskaber og værdier, foreningsidrætten tillægges, som indebærer, at medlemskab af en idrætsforening børn anses som en afgørende faktor for børn og unges liv, men som jeg vil påstå samtidig betyder, at nogle børn bliver sat i sociale kategorier, hvor de er udsatte i dobbelt forstand.

\section{DE FRIVILLIGE IDRATSFORENINGERS BETYDNING I ET POLITISIK PERSPEKTIV}

Kulturelt set er de frivillige foreninger i Danmark blevet tillagt en høj samfundsmæssig værdi, og her er foreningsidrætten ingen undtagel- 
se. Det positive syn på foreningsidrætten har rødder i en historisk udvikling, som er tæt vævet sammen med udviklingen af det moderne danske velfærdssamfund, og dermed også med udviklingen af demokratiet og det aktive medborgerskab. Fra politisk side er der stor velvilje og tillid til idrættens organisationer og foreninger. I de seneste år er der kommet øget politisk fokus på idrætsforeningers potentiale $\mathrm{i}$ forhold til løsning af velfærdsopgaver inden for områder som sundhedsfremme og integration. Der er en forventning om, at idrætsforeninger både er i stand til at varetage opgaverne, men også at foreningerne er det rette sted for varetagelsen af den slags velfærdsarbejde. Derudover indgår et økonomisk aspekt, da idræt gennem foreningsdeltagelse er en billig løsning. Målsætningen med de mange projekter, der etableres i kommunalt regi, er derfor, at børn og unge, der ikke dyrker foreningsidræt, gennem interventionerne skal gøres foreningsaktive.

Tilliden til foreningsidrætten og dens kvaliteter $\mathrm{i}$ forhold til at udfylde en positiv funktion $\mathrm{i}$ børn og unges fritidsliv har fra politisk hold altid været stor. Ifølge historiker Morten Mortensen har de værdier, som idrætsforeningerne står for - værdier som frivillighed, nærhed og venskab - i den politiske filosofiske tankegang været positivt ladet (Mortensen, 2004). I den politiske tænkning er den foreningsbaserede idræt tilknyttet en stærk symbolværdi, eller med sociologen Bourdieus kapitalbegreb kan man sige, at foreningsidrætten har opnået en høj grad af symbolsk kapital (Østergaard, 2011a, Østergaard, 2011b). Den positive værdi, som idrætsforeningerne historisk set er blevet tillagt fra politisk side, er de seneste år blevet forstærket af den gennemslagskraft, som sociologen Robert D. Putnams udlægning af begrebet social kapital (Putnam, 2000) har haft i den politiske tænk- ning. Putnam er hverken den første og/eller eneste sociolog, der anvender begrebet social kapital, men det er først med hans udlægning af begrebet, at det har bevæget sig fra den akademiske verden til den politiske. Det er Putnams udlægning af begrebet social kapital, der for alvor har gjort, at social kapital i dag indgår som en del af den politiske strategi. Putnams begreb om social kapital indbefatter de sociale netværk, der i et samfund etableres mellem mennesker. I Putnams udlægning rummer begrebet social kapital både en strukturel komponent i form af netværk og en kulturel komponent i form af normer, men det er især den strukturelle komponent, Putnam vægter i sine studier. Putnams udlægning af begrebet social kapital har givetvis opnået sin popularitet i den politiske verden, fordi Putnam operationaliserer social kapital til kvantificerbare mål. Det åbner op for en forestilling om, at det er muligt at måle graden af eksempelvis tillid i et samfund, lige så vel som det gør det muligt gennem politiske interventioner at øge den samfundsmæssige effektivitet ved at skabe rammer, som øger et samfunds sociale kapital (Putnam, 2000). Ifølge Putnam er frivilligt arbejde og foreningsmedlemskab netop to af de centrale parametre, der øger et samfunds sammenhængskraft. At Putnams teori har vundet politisk indpas, kan blandt andet ses i regeringsgrundlaget fra 2010 Danmark 2020 - viden, vakst, velstand, velfard, hvor et af konkurrenceparamenterne er en målsætning om at opnå øget tillid. Et af de ti punkter på listen opstillet i regeringsgrundlaget lyder: "Danskerne skal være et af verdens mest tillidsfulde folk «. Putnams begreb om social kapital er i dag en del af policy inden for områder som folkesundhed, men også inden for økonomi. På den måde indgår social kapital, eksemplificeret i regeringens tipunktsprogram som et måle- 
og konkurrenceparameter i de nationale staters globale konkurrence (Pedersen, 2011). Den vægt, foreningsdeltagelse tillægges, skal ses på baggrund heraf. Foreningsdeltagelse bliver fra politisk side ikke kun tillagt værdi i forhold til den enkeltes liv og kompetenceudvikling og $\mathrm{i}$ forhold til sammenhængskraften i det lokale samfundsliv. En høj foreningsdeltagelse har også politisk værdi i det globale spil, hvor stater konkurrerer indbyrdes.

\section{FORENINGSDELTAGELSE BLANDT BøRN}

Foreningsdeltagelsen $\mathrm{i}$ det organiserede foreningsliv er høj i Danmark. Næsten alle børn i 7-15 års alderen går i en kortere eller længere periode til foreningsidræt. Ifølge Maja Pilgaards undersøgelse af danskernes idrætsvaner (Pilgaard, 2009) svarede kun $11 \%$ af børn og unge $\mathrm{i}$ aldersgruppen, at de ikke har deltaget $\mathrm{i}$ foreningsidræt inden for det seneste år. Vi har en kultur i Danmark, hvor det snarere er reglen end undtagelsen, at børn dyrker foreningsidræt i deres fritid. At børn er medlem af en idrætsforening, bliver med et af Bourdieus begreber dermed en del af den doxa, det danske samfund bygger på. Det vil med andre ord sige, at foreningsdeltagelse bliver noget, som tages for givet. Derfor stilles der ikke spørgsmål til rigtigheden af, at alle samfundsgrupper skal underlægges idrætsdeltagelse i foreningsregi. Når det gælder styring og problemidentifikation i det politiske spil, skabes magtudøvelsens genstand ifølge professor Signild Vallgårda på baggrund af kategoriseringer af problemer og mennesker. Kategoriseringerne hjælper til at reducere kompleksiteten, så der kan skabes »et afgrænset felt som regulerer, hvad der kan siges og hvad der ikke kan siges« (Valgårda, 2003, s. 12). Anvender jeg anskuelsesmåden $\mathrm{i}$ forhold til problemstillingen vedrørende forsøget på gennem utallige interventioner at gøre foreningsløse børn foreningsaktive, må jeg udlede af mine empiriske data, at forståelseskategorier og interventioner ikke nødvendigvis er skabt ud fra målgruppens behov. Tværtimod ser det ud, som om problemidentifikation og problemløsning er produceret ud fra et reguleringssystem, der tager udgangspunkt i doxa, det vil sige majoritetens normer, og som derfor er bygget op efter en logik, der er genkendelig på de forskellige niveauer i det administrative og udøvende system. At man gennem denne form for kategoriseringsdannelse af problemer og mennesker lukker af for alternative vinkler og løsningsforslag, bliver med Pilgaards undersøgelse tydeliggjort af, at der er en social ulighed $\mathrm{i}$ forhold til foreningsmedlemskab. Hendes undersøgelse viser, at de børn, der ikke dyrker foreningsidræt, oftest er at finde blandt den gruppe af børn, man betegner som socialt udsatte. I gruppen af socialt udsatte befinder sig børn af forældre med anden etnisk herkomst, børn i familier med lav økonomisk indkomst og børn, der kun bor hos enten mor eller far. Men hendes undersøgelse viser samtidig, at gruppen af foreningsløse børn dyr-

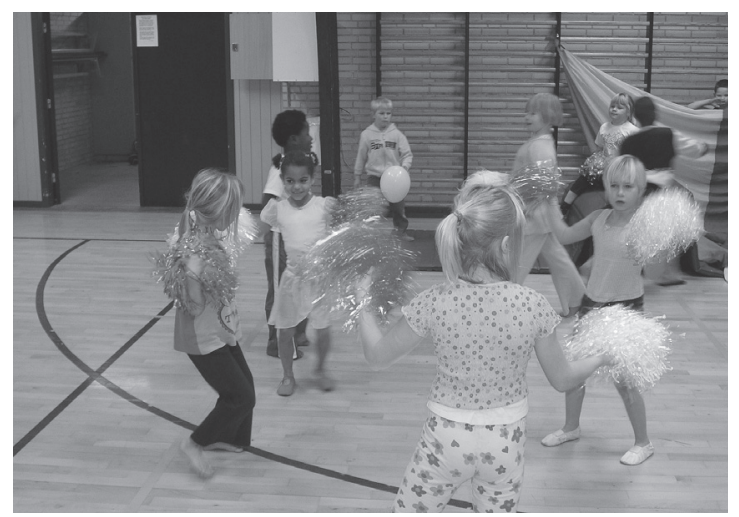

Fotografiet er udlånt af Dansk Skolesport. 
ker mere idræt i SFO/fritidsklub end andre børn. Om dette fænomen skriver Pilgaard:

"Det er interessant, da disse børn generelt ikke dyrker så meget sport og motion og $\mathrm{i}$ øvrigt er mindre tilbøjelige til at indgå i foreningsidrætten. Men noget tyder altså på, at de gerne vil være med til idrætsaktiviteter, når det foregår i SFO/fritidsklubben«. (Pilgaard, 2009, s. 113)

Både Pilgaards undersøgelse og mine studier peger på, at de børn, jeg her har kaldt de foreningsløse børn, ikke udebliver fra idrætsforeningernes tilbud, fordi de ikke kan lide eller ikke ønsker at dyrke idræt. De peger derimod på, at de er idrætsaktive, hvis de bliver tilbudt idræt under andre organiseringsformer. Både politisk og forskningsmæssigt har man kategoriseret børn, der ikke er medlem af en idrætsforening, som fysisk inaktive eller idrætsinaktive. Med andre ord er kategorier som idrcetsinaktive børn brugt om børn, der ikke går til foreningsidræt. Fra et kvantitativt studie, hvor man med accelerometre har målt på børns fysiske aktivitetsniveau (Nielsen et al., 2009), har man i dag forskningsmæssigt belæg for at sige, at danske børn i indskolingsalderen (6-10 år), der ikke dyrker foreningsidræt, er lige så fysisk aktive som børn, der dyrker foreningsidræt. Disse børn er bare fysisk aktive på en anden måde, eksempelvis ved at dyrke uorganiseret idræt. Jeg vil derfor hævde, at man kan tale om, at der eksisterer en børnegruppe, som typisk findes i lavindkomstfamilier og i gruppen af børn med anden etnisk baggrund end dansk, som bliver udsat for symbolsk vold i dobbelt forstand. Både på grund af de kategorier, der bliver produceret om børnene, men i lige så høj grad fordi de forskellige interventioner går ud på at få dem tilpasset, så de kan fungere i den danske foreningskultur. Det forhold, at børn i Danmark, der ikke er medlem af foreningsidrætten, automastik bliver koblet til en forestilling om inaktiv idrætsdeltagelse, bemærker den amerikansk fødte antropolog Sally Anderson i sit feltarbejde om danske børns idrætsdeltagelse (Anderson, 2008). Om konstruktionerne $\mathrm{i}$ forhold til en bestemt børnegruppe skriver hun:

"During fieldwork, it was impossible to ignore the category associationless children and efforts to channel this category of children into association sport. With reference to their lack of participation in organized sports, urban children, particularly 'immigrant children', were categorized as 'sportweak,' 'sport passive' or "sport- foreign.« (Anderson, 2008, s. 102)

\section{HVOR PRODUCERES DEN SOCIALE KAPITAL?}

En høj grad af social tillid bliver i dag betragtet som en komparativ fordel. Derfor indgår det som nævnt som et produktions- og konkurrenceparameter i det politiske spil. Når regeringen derfor gennem økonomisk støtte til interventioner ønsker, at flere af samfundets borgere, og i særligt grad børn og unge, skal gå til idræt i en idrætsforening, handler det ikke kun om, at man ud fra et sundhedsmæssigt synspunkt ønsker, at de skal være fysisk aktive. Ønsket er i lige så høj grad, at en gruppe børn og unge indgår i foreningslivet for at tilegne sig bestemte former for social og kulturel kapital. Kapitalformer, som senere kan konverteres og anvendes i andre sammenhænge, eksempelvis på arbejdsmarkedet. Derfor bliver det nærliggende at spørge, om der ud fra en kulturel og social vinkel er forskel på, om aktiviteterne foregår på skolen eller i en forening. Her vægtes dog kun spørgsmålet om den sociale kapital.

Mine data fra de to undersøgelser tyder på, at 
børnene i høj grad opbygger social kapital ved at gå til skolesport og ISA. Den sociale kapital, der oparbejdes $\mathrm{i}$ forbindelse med deltagelse $\mathrm{i}$ idrætsaktiviteter organiseret under Skolesport og ISA, er en social kapital, som en del af børnene på grund af deres udsathed ikke har mulighed for at opnå i det traditionelle foreningsliv. Ifølge interviews med de tilknyttede lærere i projekterne Skolesport og ISA er foreningsidrætten ikke altid den bedste og mest oplagte fritidsaktivitet for udsatte børn. En af lærerne forklarer det med, at nogle børn har behov for et andet tilbud end det, idrætsforeningerne kan tilbyde. Tilbuddene til udsatte børn skal efter lærerens erfaring være tilbud, hvor det »ikke drejer sig, om at man skal være den bedste, og man skal til opvisning eller have pænt tøj på og skrues ned i en trikot, der ser ud af helvedes til, hvis man har lidt deller« (Interview med skolelærer). Det skal med andre ord være tilbud, hvor der eksisterer en anden logik end præstationsog rangordenslogikken. Det skal være tilbud, som har fokus på leg frem for konkurrence. Både skolesport og ISA har blandt andet succes med at indfange og fastholde målgruppen, fordi de har en anden målsætning og en anden logik indbygget, som er langt mere socialt orienteret og langt mindre konkurrencepræget. Idrætslærerne kan på grund af deres faglighed og kendskab til eleverne afstemme aktiviteterne efter børnenes formåen og kompetencer og dermed gøre idrætsdeltagelsen til en succesoplevelse.

Det må her stå som et åbent spørgsmål, om den sociale kapital, der bliver produceret gennem børns og unges deltagelse i idrætsforeningen, har en større tillidsskabende og netværksdannende karakter end den, der bliver produceret gennem ISA og Skolesport. Det kunne være interessant at undersøge, om der bliver produceret mere social kapital i foreningerne end gennem de idrætsaktiviteter, der eksempelvis bliver arrangeret i skolregi. Umiddelbart er det vanskeligt at undersøge og finde svar på fordi en del af årsagen til, at nogle børn ikke dyrker foreningsidræt, ligger i forældrenes manglende opbakning. Den sociale kapital, et barn opnår ved at være foreningsaktiv, handler om mere og andet end barnet selv. Det handler også om den anerkendelse og den støtte til netværksdannelse, barnet opnår gennem forældrenes engagement. Barnets selvværd bliver støttet af forældrenes engagement, men også barnets netværk støttes gennem de kontakter, forældrene skaber indbyrdes, gennem de uformelle samtaler på sidelinjen ved træning og kampe og gennem samarbejde om kørselsordninger og lignende. Netværksdannelse gennem forældreopbakning ser ikke ud til at være muligt på samme måde at skabe i skoleprojekterne, fordi disse børns sociale udsathed også handler om forældrenes manglende overskud til engagement i barnets (fritids)liv. Til gengæld oparbejdes der gennem de idrætsaktiviteter, der foregår på skolen, andre former for social kapital. Både ISA og Skolesport er årsag til udvidede kontaktflader og netværk eleverne imellem. I begge projekter indgår elever fra skolens ældste klasse som trænere/hjælpetrænere. Det fremhæves som en stor gevinst for det sociale miljø på skolerne, at der på grund af idrætsaktiviteterne opstår nye relationsdannelser på tværs af årgange. Idrætsaktiviteter på skolen efter skoletid ser ud til at mindske hærværk og mobning og akkumulerer dermed efter idrætslærernes udsagn øget tryghed og tillid på og omkring skolen. Således handler det at gå til ISA eller Skolesport om mange af de samme ting, som foreningsidrætten handler om, det vil sige at skabe positive sociale relationer, øge sit netværk og øge tilliden i lokalsamfundet. 


\section{SKOLEN SOM TILLIDSSKABENDE INSTITUTION}

Putnam bygger sin analyse af social kapital og tillid på forskelle, han observerer i lande, der er kulturelt forskellige, men Putnams glemmer dog ifølge professor Lars Henrik Skov, at tillid ikke er ligeligt socialt fordelt. Man ved ifølge Skov fra undersøgelser, at tillid til andre personer og institutioner varierer $\mathrm{i}$ forhold til individernes sociale position, og at det er lettere at udvise tillid, hvis man befinder sig i en privilegeret samfundsposition. Man ved med andre ord, at mængden af tillid er socialt differentieret $\mathrm{i}$ forhold til mængden af et individs kulturelle og økonomisk kapital. Lars Henrik Skov kritiserer Putnams teori for, at "den i sin kerne hviler på en 'partikularistisk' forståelse af tillid baseret på tilhørsforholdet til et historisk skabt kulturelt fællesskab« (Henriksen, 2011, s. 60), hvor normer og værdier er definerede på forhånd, hvilket, som Henriksen skriver, privilegerer en bestemt moralsk diskurs.

I de samtaler, jeg har haft med idrætslærere, hvoraf nogle af dem samtidig er frivillige trænere i idrætsforeninger, kommer det frem, at der, når det gælder familier med anden etnisk herkomst, er forskel på den tillid, de viser over for deres børns idrætsdeltagelse i skoleregi, og den, de udviser $\mathrm{i}$ forhold til deres deltagelse $\mathrm{i}$ foreningsidræt. Generelt er der stor skepsis over for foreningslivet, hvorimod der udvises tillid til skolen som institution og lærerne som fagpersoner. En samtale med en idrætslærer, der samtidig er træner i en fodboldklub, som ligger tæt på skolen, illustrerer den forskel, idrætslærerne oplever i forhold til familiernes tillid. Skolens særlige rolle som tillidsskabende institution bliver tydeliggjort, da vi kommer ind på børnenes mulighed for at deltage i stævner, turneringer og lignende arrangementer. Idrætslæreren for- tæller, at når det gælder arrangementer i forbindelse med ISA, er der aldrig nogle problemer med børnenes deltagelse. Den symbolske værdi, skolen har som institution, ser ud til at sikre, at børnene får lov at tage med ud til stævner. Samme velvillighed er ifølge idrætslæreren ikke tilstede, når det handle om stævner og kampe på udebane i boldklubben. Idrætslæreren har $\mathrm{i}$ samarbejde med en anden af skolens lærere oprettet pigehold i boldklubben, hvor de træner nogle piger af anden etnisk baggrund, som tidligere deltog i ISA. Gennem sin autoritet som lærer har han opnået forældrenes samtykke til, at pigerne spiller fodbold $i$ foreningsregi. Han fortæller, at det ikke har været uproblematisk. Skal pigeholdene eksempelvis spille kampe på udebane, opstår der mistillid fra forældrenes side. Idrætslæreren fortæller, at forældrene ringer til ham midt under kampene og blandt andet kan finde på at spørge:

„Er I færdige med kampen? Så siger jeg 'nej, hende 8'eren kan jeg ikke lige nå, vi er ikke færdig med kampen og vi er hjemme sådan og sådan..’ Der bliver tjekket, og når jeg har parkeret bilen herude, så er der nogen som bor her, der kan se, det er (ham læreren) ovre i bilen, den er god nok, det er ham, og hvis det ikke er mig, så skal de vide, hvem det er« (Interview med skolelærer).

Min undersøgelse viser, at skolen som institution og dens ansatte i kraft af deres faglighed er med til at legitimere de idrætsaktiviteter, der foregår på skolen. Gennem lige adgang til uddannelse er skolen som velfærdsinstitution en væsentlig tillidsskabende institution. Det kan være en forklaring på, at det er lettere for forældrene at give deres børn lov til at dyrke idræt på skolen. 


\section{OM KONKURRENCELOGIKKEN OG DE ANDRE LOGIKKER I IDRATTEN}

I et praksisnært perspektiv udfylder Skolesport og ISA et hul i udbuddet af idrætsaktiviteter til børn og unge. ISA og Skolesport danner i kraft af forankringen på skolen en ramme om idrætsdeltagelse, som forældre til socialt udsatte børn har tillid til. Derudover er de opbygget efter en anden logik end foreningsidrættens.

Idrætten udvikler sig ligesom alt andet i samfundet, foreningsidrætten er ikke som tidligere det eneste sted at gå hen. Fitnesskulturen har i de seneste år været i vækst, dog i mindre grad hos børn end voksne, men også selvorganiserede miljøer med aktiviteter som skateboard, rulleskøjteløb og parkour etablerer sig og føjer sig til udbuddet af idrætsaktiviteter. Aktiviteterne opstår i nye miljøer og subkulturer, hvorfor de som udgangspunkt har en anden organisering, logik og regelsæt indbygget. Men selvom der er kommet nye idrætsaktiviteter og nye foreningstyper, ændrer det ikke ved, at de idrætsaktiviteter, de fleste børn i dagens Danmark kommer i berøring med, er aktiviteter, der foregår i idrætsforeningerne (Pilgaard, 2009), der stadig langt de fleste steder er præget af en logik, som bygger på præstation, og dermed i sig har indbygget en konkurrence- og rangordningslogik (Engström, 2010). Den præstationsprægede tilgang til idræt er stærk i foreningskulturen, og tendensen bliver forstærket af, at der som oftest sker det med de nye aktivitetsformer som eksempelvis skateboard, rulleskøjteløb og parkour, at de for at opnå adgang til faciliteter i form af lokaler og baner organiserer sig i foreninger. De nye aktivitetsformer gennemgår med andre ord det, som den amerikanske historiker og sociolog Allen Guttmann i sin karakteristik af den moderne idræt har kaldt sportificering (Guttmann, 1978). Selv inden for fitnesskulturen er logikken præ- get af en præstationslogik; her er kampen ikke ydre men indre, her skal præsteres en smukkere, sundere og mere fuldendt krop. Der er med andre ord ikke mange steder at gå hen, hvis man som barn ikke føler sig tiltrukket af den præstationsprægede tilgang til at bevæge kroppen.

\section{IDRAT PÅ SKOLEN EFTER SKOLETID, BEHOVET FOR EN ALTERNATIV INSTITUTIONALISERING OG ORGANISERINGSFORM}

Der er meget, der taler for, at tyngden i interventioner målrettet foreningsløse børn bør ligge i det tilbud om idræt, der finder sted på skolen efter skoletid. Det har længe været en myte, at har man dyrket foreningsidræt $\mathrm{i}$ barndommen, så er sandsynligheden for, at man dyrker idræt som voksen, større. Den svenske sociolog LarsMagnus Engström har i et longitudinelt studie om den svenske befolknings smag for og dyrkning af idræt og motion (Engström, 2010) påvist, at foreningsdeltagelse som barn ikke har betydning for, om man er fysisk aktiv som voksen. Forklaringen er, at den logik, der ligger bag voksnes motions- og idrætsdeltagelse, er en anden end logikken i foreningsidrætten. Engströms resultater viser, at nogle af de væsentligste faktorer, som har betydning for, om man som voksen er fysisk aktiv, er den karakter, man fik i idrætstimerne i folkeskolen samt det forhold, at man har været udsat for alsidig idræt. Vil man derfor fra politisk side skabe borgere, som også i voksenlivet er fysisk aktive, bør man i højere grad satse på at udvikle tiltag i skolen, som fremmer bevægelsesglæde og idrætslig alsidighed. Min undersøgelse af ISA og Skolesport viser, at der godt kan dannes vellykkede netværk mellem skole og foreningsliv, og at foreningerne kan bruge netværket til at spotte og indfange interesserede og talentfulde børn og unge. Men undersøgelsen viser også, at foreningsidrætten i 
kraft af dens indbyggede logik om præstation og konkurrence og i kraft af dens særlige kulturelle organisering ikke altid er den mest optimale model for idrætsdeltagelse i forhold til særlige målgrupper.

\section{LITTERATURLISTE}

Anderson, S. (2008). Civil Sociality - Children, Sport, and Cultural Policy in Denmark. United States of America: Information Age Publishing, Inc.

Dansk Skoleidræt og Dansk Idræts-Forbund (2003). Dansk Skoleidraet og Dansk Idrcets-Forbunds ansøgning om tilskud til Projekt Skolesport. Nyborg d. 29 oktober 2003 (Upubliceret tekst).

Engström, L.-M. (2010). Smak för motion - Fysisk aktivitet som livsstil och social markör. Stockholm: Stockholms universitets förlag.

Guttman, A. (1978). From Ritual to Record: The Nature of Modern Sport. New York: Columbia University Press.

Henriksen, L. S. (2011). »Tillid - et spørgsmål om moral? « Dansk sociologi, nr. 2/22. årg. København.

Mortensen, M. (2004). Idraet som kommunal velfard. Mentalitet, velfard og idrcetspolitik $i$ København, Ballerup og Skive 1870-1970. Institut for Idræt, Københavns Universitet.

Nielsen, G., Grønfelt, V., Toftegaard-Støckel, J. \& Andersen, L. B. (2009). "Predisposed to participate? The influence of family socio-economic background on children's sports participation and daily amount of physical activity«. Sport in Society (in press).

Pedersen, O. K. (2011). Konkurrencestaten. København: Hans Reitzels Forlag.

Putnam, R. (2000). Bowling Alone: The Collapse and Revival of American Community. New York: Simon and Schuster.

Theilgaard, L. (2008). Projektbeskrivelse Idraet og Samvaer (ISA). Børne- og Ungdomsforvaltningen, Københavns Kommune (Upubliceret tekst).

Vallgårda, S. (2003): Folkesundhed som politik. Danmark og Sverige fra 1930 til i dag. Magtudredningen. Århus: Aarhus Universitetsforlag.

Østergaard, C. (2008). Projekt Skolesport - Mere idraet og bevagelse i krydsfeltet mellem skole, elev, forening og kommune. Institut for Idræt, Københavns Universitet.

Østergaard, C. \& Pedersen, L. W. (2011a). „Bourdieu - smag, distinktion og idrætten som et socialt felt«. I: L. F. Thing \& U. Wagner (red.), Grundbog $i$ idrcetssociologi. København: Munksgaard.

Østergaard, C. (2011b). Fysisk aktivitet som forebyggende og sundhedsfremmende strategi - en undersøgelse af fysisk aktivitet og idraet brugt som forebyggelse og sundhedsfremme i to udvalgte kommuner. Institut for Idræt, Københavns Universitet. Ph.d. afhandling. 